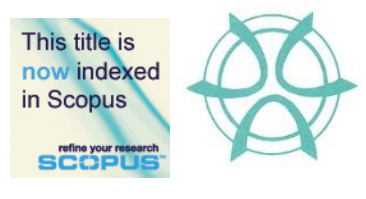

PLANNING MALAYSIA:

Journal of the Malaysian Institute of Planners

VOLUME 16 ISSUE 3 (2018) Page 24 - 35

\title{
ILLEGAL HOUSE RENOVATIONS: IMPROVING THE RENOVATION GUIDELINES OF A LOCAL AUTHORITY THROUGH PUBLIC PARTICIPATION
}

\author{
Yazid Sarkom ${ }^{1}$, Mimi Zaleha Abdul Ghani' ${ }^{2}$ \& Md. Najib Ibrahim ${ }^{3}$ \\ ${ }^{1,2,3}$ Faculty of Architecture, Planning and Surveying \\ UNIVERSITI TEKNOLOGI MARA, MALAYSIA
}

\begin{abstract}
Illegal house renovations have created numerous problems to local councils in Malaysia. Enforcement work have cost unnecessary financial burden to local councils as well as losses to the house owners. Hence, this research is aimed at investigating the issues associated with illegal house renovations in a local council and exploring the responses from the local council's stakeholders on the possibility of involving the public in reframing the house renovation guidelines. A qualitative research method of focus group discussion was held among the related stakeholders in Ampang Jaya Municipal Council (MPAJ). The findings indicated that the problems with illegal renovations are mainly due to the unsuitable guideline itself, the level of understanding of the public, the unrestrained small contractors and the complicated enforcement procedures. The council's stakeholders also agreed that more community involvement is encouraged in restructuring the existing renovation guideline, but not to the extent of giving the public all the rights to decide the final outcome.
\end{abstract}

Keywords: illegal house renovation, renovation guideline, public participation 
PLANNING MALAYSIA

Journal of the Malaysia Institute of Planners (2018)

\section{INTRODUCTION}

An illegal building renovation is a building refurbishment or extension without approved renovation plans by the local council or a renovation work that does not adhere to the approved renovation plan. Approved building plans are important to confirm the safety and health of the users and public. This paper aims to investigate the issues of illegal house renovations and the role of public participation in reforming renovation guidelines. A case study was conducted in the Ampang Jaya Municipal Council (MPAJ), Selangor, a neighboring local council to the capital city of Malaysia, Kuala Lumpur. MPAJ is a local council that has evolved from a small tin mining town in a Klang Valley to become a locality of 600,000 people in the year 2009 (MPAJ official portal). Being the eight most densely inhabited local Authority in Malaysia (Jaafar 2004), MPAJ was chosen as a case study to investigate the issue due to its diversity in the social and economic status of the residents. To achieve the aim, the objectives of this study are initiated by attempting to investigate whether the building renovation guidelines of the local council reflect the needs of the community. Subsequently, the study seeks to gauge the stance of the stakeholders on the need of public involvement in drawing up the renovation guidelines; and lastly, the study attempts to explore the public participation models that can enhance the process of house renovation guidelines.

\section{RESEARCH BACKGROUND}

Studies in several parts of the world on house renovation compliance with the local authority's requirements have found out several reasons for noncompliance. A research conducted in Old Salt, Jordan by Alnsour and Meaton (2009) revealed that the diversity in the social and financial status of a community as well as the level of understanding of the regulation affects the obedience to building regulations. Meanwhile, Rukwaro (2009), in his study in Nairobi, Kenya revealed that incompatible building guidelines with the community's necessity contributed to illegal building works. He also cited that Elaziah (1988) exposed that the ineffective administration of enforcement works within the departments of a local authority also contribute to the public's confusion. Yau and Chiu (2015) however, concluded that rising building penalty and enforcement are more suitable to contain the issues of illegal building renovations in Hong Kong.

While building control is important to protect the safety of the public, some studies suggested that the regulation also causes unnecessary burdens to the people (Burby, Malizia, \& May, 1999). The British government had organized a thorough evaluation covering all aspects of building regulations to stimulate the construction industry and to improve the economy (The Guardian, 2012). On the same note, the American president, Mr. Donald Trump has also recognized these circumstances and had issued an Executive Order (EO) 13777 on 24 February, 2017 to the American government agencies to evaluate the existing American 
Yazid Sarkom, Mimi Zaleha Abdul Ghani \& Md. Najib Ibrahim

Illegal House Renovations: Improving the Renovation Guidelines of a Local Authority Through Public Participation

regulations to make them less burdensome to the public (Office of the Federal Register, 2017). The EO subsequently required the relevant departments to conduct public comment inputs. In Malaysia, the government has launched a new program called National Transformation 2050 "TN50" on 19 January 2017. Many of the government agencies have embarked on the new program which calls for more public engagements. For example, the police force has initiated a community engagement programme called "Talk to Us" which has obtained a very good feedback from the community (Bernama, 2017).

Building renovation guidelines in local authorities regulate house renovations in Malaysia. While state authorities in Malaysia have the Town and Country Planning Act (Act 172) for new housing projects, renovation guidelines are mainly left by the state planning authorities to local authorities to formulate. For example, the Manual Guideline and Selangor State Planning Standards (JPBD Selangor, 2010) states the planning requirements of new buildings, but does not state clearly the requirements for building renovations. Thus, local authorities set the renovation guidelines according to the local requirements as long as not to contravene with the Road, Drainage and Building Act (Act 133) and the Uniform Building By-laws (UBBL) 1984.

The state planning department has also incorporated public participation in their planning processes, as required by Act 172. However, the approach has not transformed much, although many new forms of public participation have been developed (Maidin, 2011). Act 172 only allows the public to give opinions and responses while the local authority's committee will decide the final outcome. So, this study will inquire the stakeholders on whether the public should be involved in the framing of the renovation guidelines and to what extent should they be allowed to participate.

\section{RESEARCH METHODOLOGY}

A qualitative research of focus group discussion was conducted in MPAJ consisted of stakeholders involved in the approval of house renovation plan. There were five directors and two deputy directors from MPAJ, representing Planning Department, Building Department, Engineering Department, Legal Department, Valuation and Asset Management Department, Enforcement Department and Urban Management Department. Others in attendance were an architect, an engineer, two registered building draftsmen and a MPAJ local councilor. The discussion took place at the MPAJ main office building and the session lasted for about 2 hours and 15 minutes. The medium of discussion is mainly Malay language with English language used intermittently. The group was guided by a set of key themes according to the three objectives of this study. However, the participants were allowed to develop their own views and judgments with minimal intervention along the session. The focus group discussion was aided by a visual presentation and was digitally recorded by using 
PLANNING MALAYSIA

Journal of the Malaysia Institute of Planners (2018)

two audio-recorders and the audio recordings were then transcribed into English language text.

\section{FINDINGS AND RESULTS}

From the focus group discussion, several key issues have been discovered in relation to the topics outlined in the focus group process. For the purpose of data analysis, the issues raised throughout the discussion were then rearranged according to the following categories.

\section{Issues Associated with House Renovations in MPAJ}

\section{The Renovation Guidelines}

There were several problems raised with regards to the existing renovation guideline itself. In the first place, the term "guideline" was questioned by participant A. He argued that a procedure in a local council can only become a guideline if it was endorsed by the State Government. However, participant B explained that as practiced by many local councils, the local rules still apply since local councils have the power to make their own exclusive procedures as vested to them via the Local Government Act 1976 (Act 171). This situation, however, has created conflicting requirements and procedures of house renovation guidelines among the local authorities in Selangor and other states in Malaysia.

When the focus group was questioned whether the renovation guidelines has served the community's need, participant B explained that since the formation of MPAJ in 1992, the current MPAJ's renovation guideline has undergone various changes to accommodate the inspirations of the Yang Dipertua (Mayor) of the council and local councilors of the day, or to rationalize certain irregular issues that emerged. The Mayor and councillors keep changing due to their twoyear term appointments and they may be renewed or replaced after they have served their terms on the council. All the renovation guideline's changes were endorsed by the council's full board meeting after reviews and revisions by the planning and building committee of MPAJ which consists of technical departments and local councillors. However, participant $\mathrm{C}$ insisted that even though the guideline was endorsed by the local council, it should tally with the state planning guidelines. Nonetheless, as mentioned previously, the state planning guideline is mainly for a new housing scheme, not for renovation of an existing house. Another pertinent issue is all the changes were done without directly involving the public consultation, thus, all the changes do not really reflect the public needs as a whole.

Participant $\mathrm{F}$ informed that among the problems that the public normally faced with the current MPAJ's guideline is the regulation on building setback, citing that the current setback requirement for renovation is too stringent. "If the public knows that their proposed renovation can be approved by the council, then 
Yazid Sarkom, Mimi Zaleha Abdul Ghani \& Md. Najib Ibrahim

Illegal House Renovations: Improving the Renovation Guidelines of a Local Authority Through Public Participation

the tendency to submit the renovation plan is higher" he said. He gave an example of the latest renovation guidelines improvement in the Kuala Lumpur City Hall (DBKL), implemented since 1 January 2017. DBKL has now allowed house owners to renovate their house up to the maximum available space within their lot boundary and allowed to add an additional third storey to an existing twostorey terrace house (Figure 1). Further study of the recent DBKL's renovation guideline found out that DBKL has made the revision because the current price of houses is very high in Kuala Lumpur and the increase of family members requires the existing houses to be extended instead of having to buy a new house. The DBKL guideline differs from MPAJ's as it allows more building extension at the front of the building and it also permits for an additional third storey.

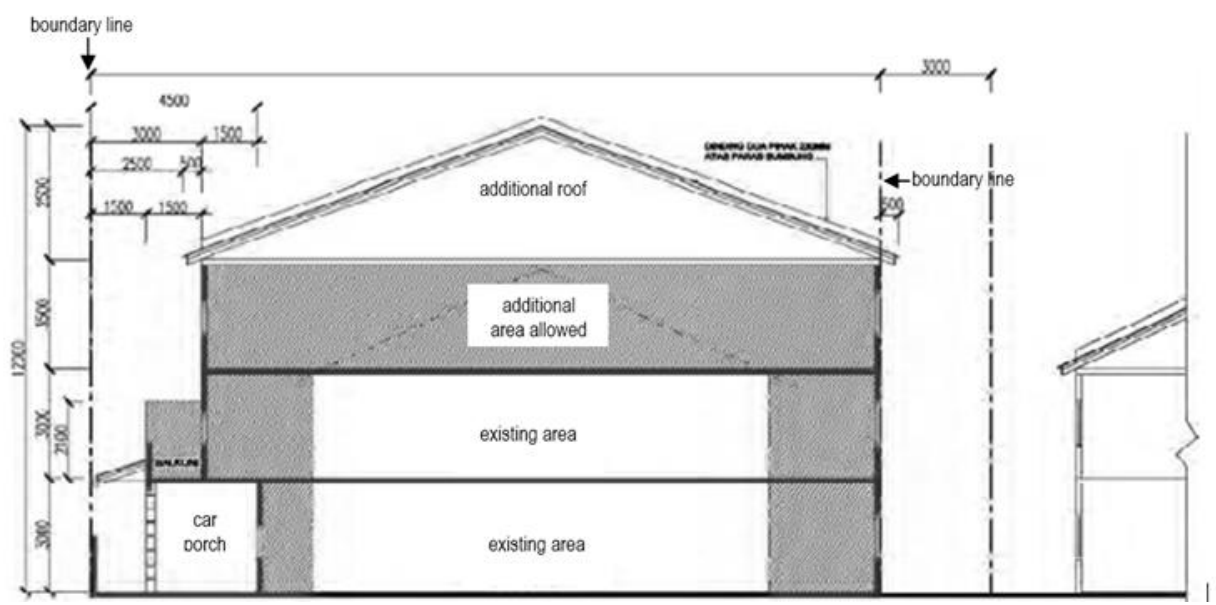

Figure 1: Sectional view of a renovation guideline for a two-story terrace house in Kuala Lumpur

Source: Building Control Department (2017)

Participant D said that some residents complaint that there are too many requirements before a renovation plan can even be accepted by the council. The supporting documents required on top of the building plans are the land title or the sale and purchase agreement of the house, payments of assessment to the council, quit rent to the land office, consents from adjacent neighbours, deposit for compliance with the approved plan, fee for removal of debris and fees for the deposit of building materials on the public area. A study on other local councils in Selangor has discovered similar requirements, although with some variances. Therefore, there should be a re-evaluation whether there are some overlapping, redundant, or superseded documents. 
PLANNING MALAYSIA

Journal of the Malaysia Institute of Planners (2018)

\section{The Community}

Some of the members of the community do not even know that they must submit a renovation plan for their building renovation work and those who have done so were often because they were also applying for a renovation loan from the banks or the government, said participant B (the loan institutions normally require the approved plan for a renovation loan approval). However, participant A stressed that ignorance of the law is not an excuse for not abiding the law. He also added that depending on whom the owners happen to meet, if they met a local councillor, most probably the councillor would suggest the owner to submit renovation plans before commencing any work. But, if they met a contractor, probably the contractor would say they will handle everything from applying the renovation approval and the construction work until completion. However, the owners are normally not aware of the status of the renovation plan submission. They are more interested to know that the construction work is progressing uninterrupted. Most of them will only know that the renovation work is without an approved plan after the building construction was completed and received the summons by the court. Most of the contractors would keep the earlier notices issued by the local council to themselves and not informing the house owners until after the work completed. The owner then has to deal with the problem on his own since usually it is difficult to get cooperation from the contractor when the construction payment has been fully disbursed.

The community's level of understanding about renovation plans was also raised. Participant B highlighted that most members of the public are not well versed of the technical jargons of the building plans. Sometimes, they cannot visualise the approved building plan clearly, but as the construction is progressing, they realise that it is not what they have imagined and changes have to be done straight away without informing the local authority.

Having said that, the authority should not always entertain the public complaints, said Participant B. Some house owners have not been sincere in their applications for renovation plan approvals. They applied for small works using standard plans provided by MPAJ but later, they renovated the house not according to the approved plan, usually bigger than the approved one. This situation is mainly due to cost savings, he said. For small renovations such as a simple car porch or kitchen extension, the public can use standard plans provided by MPAJ for a minimal fee, but for normal renovations they have to pay extra for consultation fees to engage an architect or a building draftsman, and for two storey renovations or above, they have to engage a structural engineer as well.

\section{The Contractors}

The occurrence of illegal renovations cannot be blamed squarely on the house owners said participant C. He said that sometimes the owners are influenced by the appointed contractor, especially those house owners who are staying in the 
Yazid Sarkom, Mimi Zaleha Abdul Ghani \& Md. Najib Ibrahim

Illegal House Renovations: Improving the Renovation Guidelines of a Local Authority Through Public Participation

same house under renovation. When the owners observe the construction site too often, the tendency to modify the design is higher and the contractors also encourage the changes as they can increase the final construction cost.

Participant $\mathrm{F}$ lamented that small local contractors are facing stiff cost competitions from foreign contractors (non- Malaysian). The house owners are attracted to the lower construction costs offered by the foreign contractors even though they know the risks that entail. The foreign contractors are normally a group of tradesmen skilled in building construction, but without proper company registration. They can offer lower construction cost, but when certain problems arise, they can just disband and disappear. To encounter the problem, he suggested local councils must assure that renovation contractors working in their regions are registered with the Construction Industry Development Board (CIDB).

A study on CIDB regulation revealed that it is in fact compulsory for a construction company to register with CIDB no matter how small the company is and the workers must also have green cards. But it seems that only CIDB and not the local authority is responsible to enforce the company registration and the green card regulation.

Talking about costs, participant $\mathrm{F}$ added that even though CIDB has produced a standard agreement between a house owner and the contractor to protect the owner against errant contractors or poor workmanship, most house owners still opt to do without it as the contractors will normally charge more construction cost if the standard agreement is used. He also suggested that every local authority should keep a registration system of small contractors working in their areas because there are some house owners who do not have a clue in finding a good and reliable contractor. The registration system would then be very helpful to the house owners and the council since the council can monitor smaller construction companies.

\section{The Enforcement}

Issues with building control enforcement were also debated. Participant B stressed that renovation works done by individual house owners are more difficult to control than big projects done by housing developers because the big projects have architects and consultants that can assure the adherence to the approved plan since after the construction work completed they are responsible to issue the Certificate of Completion and Compliance (CCC). Furthermore, the housing developers must build the houses according to the approved plans since they must also abide by the sale and purchase agreements with the house buyers. For small projects, the role of contractors is crucial because the contractors seem to have the upper hand over the main consultant in making most of the decision on the site because they interact more often with the owners. The local authority, however, views the main consultant as the party responsible for the construction. 
When there is a discrepancy on the site, the consultants often complaints that their instructions are rarely followed by the owner.

Participant B added that building control enforcements in MPAJ have faced difficulties since there are new and old housing developments, mixed together in the nearby vicinity and there are already many houses renovated even before the existence of MPAJ itself. As opposed to a new local authority in a new area, such as Putrajaya, which since its inception, it has put in place the building renovation guidelines and then the enforcement works can easily be done very stringently since there is not much resistance from the community.

Deviations from the approved plans are quite common because of the problems with enforcement method. Participant E explained that the enforcement staffs will only act if the renovation work does not have the approval permit displayed on the house front. If the approval permit is displayed, but there is a deviation from the approved plan, they generally do not have the expertise to determine such discrepancies. This situation happens because the enforcement rounds are done by general duty enforcement staffs and not building department's technical staff.

Another issue with building control enforcement is when MPAJ decided to bring a case to the Magistrate Court, the Deputy Public Prosecutor (DPP) of the court will normally advise MPAJ to offer a compound to the house owner instead of admitting the case to be heard in the court said participant B. A compound is a form of enforcement, which the offender is offered to pay a certain amount of penalty to MPAJ so that the case will not be tabled in the court. The house owners will usually pay the compound and the case is considered closed, but consequently, the illegal renovation remains standing. Furthermore, the court very rarely issues a mandatory order of demolition for illegal house renovations unless the renovations cause legal complaints from the immediate neighbours or jeopardise the safety of the occupants or neighbours. Further investigation also revealed that some local authorities prefer to issue compounds rather than bringing the case to the court because the council will actually gain revenue from the compounds. If the case is heard in the court and the court decides to fine the guilty owner instead of giving a mandatory demolition order, the proceeds from the fine will go to the court, not to the local authorities.

\section{The Role of Public Participation}

\section{The Perception of Stakeholders on Public Participation}

Participant D stressed the importance of public awareness because it is easier for everyone if the public themselves are aware of the benefits of having an approved plan for renovation work. He cited an example of an awareness campaign about the strata title management on local television by The Ministry of Housing and Local Government of Malaysia. He said the campaign has been very helpful to 
Yazid Sarkom, Mimi Zaleha Abdul Ghani \& Md. Najib Ibrahim

Illegal House Renovations: Improving the Renovation Guidelines of a Local Authority Through Public Participation

educate apartment owners of the importance of paying maintenance fees. The same can be done to inform the importance of submitting renovation plans. CIDB can also play a role in awareness campaigns, he added. CIDB can educate the small contractors about the procedure, the importance and benefits of having approved renovation plans before commencing works on the site.

Participant A stated that as MPAJ already has local councillors, he questioned whether another public participation process is needed since the councilors themselves are the representative of the public. He also questioned whether the public participation processes are for real or merely for the sake of procedures because he is concerned that in the end, it is the local government law that should also be reviewed. However, he also acknowledged that the current trend of the government today is public engagement. Participant $\mathrm{C}$ added that according to the state and federal policies, it is required that public inputs must be included in audit verification reports and innovation competitions.

There was a conflict between the house renovation regulation and the needs of the residents, participant $\mathrm{D}$ reiterated. Therefore, he really agreed that the residents should be given opportunities to convey their ideas into the formation of the guidelines. Participant $\mathrm{C}$ explained that there are two methods of public participation in the procedure of the local plan formation in MPAJ: 1) Focus group discussions; and 2) Resident involvements through road show exercises. Publicity is also one of the requirements in the preparation of a local plan and it must be advertised in local newspapers for 30 days. She also said that renovation guidelines can also be included in one of the local plan programs by including it in the term of references (TOR) of the focus group discussions. However, she also cautioned whether MPAJ is ready to take the challenges if the renovation guideline was included in the next local plan revision since MPAJ must abide by the decision of the process. Any amendment or variation to the agreed renovation guideline must be referred to the public first and this exercise can be costly and time consuming.

\section{Exploring the Public Participation Models that Can Enhance the Process of House Renovation Guidelines}

The focus group participants were explained about the relationship between consultation techniques and levels of impact in the slide presentation. Excerpt of the table is mentioned in Table 1. Shipley and Utz (2012) stated that public participation models have developed over the years and the general guidelines on the levels of community involvement suggests the expected results from different types of public engagements in planning processes. It shows the link between the public participation objectives and the increasing level of public impacts from merely providing information, up to the highest level of total empowerment for the public to make the final decision. Participant D said that at this juncture he thought that MPAJ is not ready to let go the decision-making rights to the public 
and he suggested that level 3 (involve) according to the chart is more suitable. Participant B summarized that the public should be consulted and informed of certain issues as well as the alternatives in solving the problems, but in the end, he preferred to maintain that the determining party is still the local authority with the local councillors as the representatives of the public.

Table 1: Relationship between consultation techniques and levels of impact

\begin{tabular}{|c|c|c|c|c|}
\hline Inform & Consult & Involve & Collaborate & Empower \\
\hline $\begin{array}{c}\text { Public } \\
\text { Participation } \\
\text { Goal }\end{array}$ & $\begin{array}{c}\text { Public } \\
\text { Participation } \\
\text { Goal }\end{array}$ & $\begin{array}{c}\text { Public } \\
\text { Participation } \\
\text { Goal }\end{array}$ & $\begin{array}{c}\text { Public } \\
\text { Participation } \\
\text { Goal }\end{array}$ & $\begin{array}{c}\text { Public } \\
\text { Participation } \\
\text { Goal }\end{array}$ \\
\hline $\begin{array}{l}\text { To provide the } \\
\text { public with the } \\
\text { balanced and } \\
\text { objective infor- } \\
\text { mation to assist } \\
\text { them in under- } \\
\text { standing the } \\
\text { problem, alter- } \\
\text { native, oppor- } \\
\text { tunities and/or } \\
\text { solutions. }\end{array}$ & $\begin{array}{l}\text { To obtain } \\
\text { public } \\
\text { feedback on } \\
\text { analysis, } \\
\text { alternatives } \\
\text { and/or } \\
\text { decisions. }\end{array}$ & $\begin{array}{l}\text { To work } \\
\text { directly with the } \\
\text { public through } \\
\text { out the process } \\
\text { to ensure that } \\
\text { public concerns } \\
\text { and aspirations } \\
\text { are } \\
\text { consistently } \\
\text { understood and } \\
\text { considered. }\end{array}$ & $\begin{array}{l}\text { To partner with } \\
\text { the public in } \\
\text { each aspect } \\
\text { of the decision, } \\
\text { including the } \\
\text { development of } \\
\text { alternatives and } \\
\text { the identi- } \\
\text { fication of the } \\
\text { preferred } \\
\text { solution. }\end{array}$ & $\begin{array}{l}\text { To place final } \\
\text { Decision } \\
\text { making in the } \\
\text { hands of the } \\
\text { public. }\end{array}$ \\
\hline
\end{tabular}

Source: Shipley \& Utz, 2012, adapted from the International Association for Public Participation 2005

\section{CONCLUSION AND RECOMMENDATIONS}

The summary findings from the focus group discussion (Table 2) indicated that the problems with renovation guidelines are generally due to the unsuitable guidelines to the current needs of the public, the varying level of understanding of the public towards the regulation and the complicated enforcement procedures as mentioned in the earlier studies of the literature review. Additionally, the focus group discussion also exposed that the role of small contractors doing renovation works is very central since they seem to dictate the course of renovation work over the consultants. This underpinning issue should be studied further by building regulators to comprehend the nature of works for big and small construction jobs and to differentiate the kind of regulations and guidelines suitable for each scale of the works.

The focus group also concluded that public inputs are very helpful to lay down a practical renovation guideline to be implemented and enforced. The public awareness campaign is also crucial since the effectiveness of public participation process depends so much on the level of public's knowledge (Marzuki 2015). 
Yazid Sarkom, Mimi Zaleha Abdul Ghani \& Md. Najib Ibrahim

Illegal House Renovations: Improving the Renovation Guidelines of a Local Authority Through Public Participation

Table 2: Summary findings of issues associated with house renovations in MPAJ

\begin{tabular}{|c|c|c|c|}
\hline The guideline & $\begin{array}{c}\text { The } \\
\text { community }\end{array}$ & The contractor & The enforcement \\
\hline $\begin{array}{l}\text { 1.Local councils have } \\
\text { exclusive power vested } \\
\text { in the Act } 171 \\
\text { 2. Changes in guideline } \\
\text { not involving direct } \\
\text { public input } \\
\text { 3.Building setback is } \\
\text { one of the main } \\
\text { problems } \\
\text { 4.State planning } \\
\text { guideline is mainly for } \\
\text { a new housing scheme, } \\
\text { not for renovation. } \\
\text { 5.Too many } \\
\text { requirements for a } \\
\text { renovation plan } \\
\text { submission }\end{array}$ & $\begin{array}{l}\text { 1.Ignorance } \\
\text { of the law to } \\
\text { submit plan } \\
\text { 2. level of } \\
\text { understanding } \\
\text { about } \\
\text { renovation } \\
\text { plans } \\
\text { technical } \\
\text { jargons } \\
\text { 3.Some are } \\
\text { not sincere in } \\
\text { their plan } \\
\text { applications }\end{array}$ & $\begin{array}{l}\text { 1. Can easily } \\
\text { influence the } \\
\text { owner } \\
\text { 2.Local } \\
\text { contractors } \\
\text { face stiff cost } \\
\text { competitions } \\
\text { from foreign } \\
\text { contractors } \\
\text { 3.Hard to find } \\
\text { good } \\
\text { contractors } \\
\text { 4.Owner rarely } \\
\text { uses CIDB } \\
\text { agreement } \\
\text { form as it } \\
\text { incurs more } \\
\text { cost }\end{array}$ & $\begin{array}{l}\text { 1.Individual } \\
\text { renovations are more } \\
\text { difficult to control than } \\
\text { developers' } \\
\text { 2.For small projects, } \\
\text { the contractors are } \\
\text { more dominant than } \\
\text { the consultant } \\
\text { 3. Difficulties in } \\
\text { mixed new and old } \\
\text { housing developments } \\
\text { 4.Enforcement method } \\
\text { not synchronized } \\
\text { among departments } \\
\text { 5.Compounds caused } \\
\text { illegal structures not } \\
\text { demolished }\end{array}$ \\
\hline
\end{tabular}

The stakeholders should have a more detail look on the cost and expenditure of the public participation process and also revise acts and regulations that relate to the renovation guideline. Meanwhile, the stakeholders in the focus group seemed comfortable to allow the public to directly involve in giving inputs and deliberation for an enhanced renovation guideline. However, they stopped short of liberating the final decision making to the public and had no desire to change the current status quo. Even so, the acceptance by the local council to more direct public involvement even though the community is already represented by local councilors, is a step forward towards better public participation. Further study shall investigate the public comments on the existing guidelines set by the local authorities to eventually come up with a new mutually acceptable renovation guideline.

\section{ACKNOWLEDGEMENT}

This research is made possible via a grant provided by the Ministry of Education Malaysia through the Research Acculturation Grant Scheme (RAGS) ref. no.: RAGS/1/2015/TKO/UITM/02/4. The researchers would also like to thank the YDP and staff of MPAJ, and the participants involved in the focus group discussion. 


\section{REFERENCES}

Alnsour, J., \& Meaton, J. (2009). Factors affecting compliance with residential standards in the City of Old Salt, Jordan. Habitat International, 33, 301-309.

Ampang Jaya Municipal Council portal. Retrieved 28 August 2017 from http://www. mpaj.gov.my/en/mpaj/ resources/statistics

Bernama (2017, August 1). Genovasi Malaysia training for more to improve efficiency. The Sun Daily. Retrieved 16 Disember 2017, from https://www.the sundaily. my/news/2017/08/01/genovasi-malaysia-training-more-improve-efficiencynajib.

Building Control Department (2017). Renovation guideline for a two story terrace house in Wilayah Persekutuan Kuala Lumpur. Kuala Lumpur: Kuala Lumpur City Hall.

Burby, R. J., Malizia, E. E., \& May, P. J. (1999). Beating the building code burden: Code enforcement strategies and Central City success in capturing new housing. College of Urban and Public Affairs (CUPA) Working Papers, 1991-2000. Paper 17.

Jaafar, J (2004). Emerging trends of urbanisation in Malaysia. Journal of Department of Statistics, 1, 43-54.

Jabatan Perancangan Bandar dan Desa Negeri (JPBD) Selangor (2010). Manual guideline and Selangor State planning standards (Second Edition). Selangor: Author.

Maidin, A. J. (2011). Access to public participation in the land planning and environmental decision making process in Malaysia. International Journal of Humanities and Social Science, 1(3), 148-169.

Marzuki, A. (2015). Challenges in the public participation and the decision making $\begin{array}{llll}\text { process. } & \text { Retrieved } 28 \text { August } & \end{array}$ https://www.coursehero.com/file/29017319/2pdf/

Office of the Federal Register (US) (2017). Enforcing the regulatory reform agenda: Department of Justice Task Force on Regulatory Reform Under E.O. 13777. Retrieved 28 August 2017 from http://www.federalregister.gov

Rukwaro, R. W. (2009). The owner occupier democracy and violation of building bylaws. Habitat International 33, 485-498.

Shipley, R., \& Utz, S. (2012). Making it count: A review of the value and techniques for public consultation. Journal of Planning Literature, 00(0), 1-21.

The Guardian (2012, October 26). Government orders building standards review. The Guardian. $\quad$ Retrieved 28 August 2017, from https://www.theguardian.com/politics /2012/oct/26/ government-building-standards-review-regulation.

Yau, Y., \& Chiu, S. M. (2015). Combating building illegality in Hong Kong: A policy Delphi study. Habitat International, 49, 349-356. 